\title{
Japan's strategic miscommunications: in the shadow of the pandemic Olympics
}

\author{
Nancy Snow ${ }^{1,2}(\mathbb{0}$
}

Revised: 1 December 2021 / Accepted: 11 January 2022 / Published online: 2 February 2022

(c) The Author(s), under exclusive licence to Springer Nature Limited 2022

\begin{abstract}
Japan's government failed in its management, but the people involved did not. Going forward, much will depend on the country's ability to re-tell its story to the world beyond a pandemic Olympics to that of trusted sustainability partner and place that, post-pandemic, everyone will want a chance to get to know or visit.
\end{abstract}

Keywords Japan · Olympics · Strategic communications · Public diplomacy $\cdot$ Pandemic

In 2020 Monocle magazine named Japan its number one soft power country ${ }^{1}$ for its management prowess in tackling just about everything well, from rural depopulation and the aging society ${ }^{2}$ to service industry excellence and emergency preparedness. In 2021, a year into a global pandemic, Japan maintained class act rankings across several soft power indices, including the Soft Power 30 and Brand Finance.

What these soft power snapshots have failed to capture is a persistent asymmetrical power gap between civil society and the state that results from weak strategic communications. ${ }^{3}$ The gap came to light in 2021 when the government of Japan failed to expedite a vaccine campaign tied to full preparation for the safety and security global promises of the Summer Olympics and Paralympics. The vaccine debacle, coupled with an exhausting succession of SOE measures, led to a decline in trust between citizen and state. Coronavirus fatigue set in and enthusiasm for the Olympics declined. Japanese public suspicion centered on the government playing favorites. All spectators were banned while the commercial and global broadcasting billions in profits for the International Olympic Committee and sponsors were permitted by forging ahead with a pandemic Olympics.

From the beginning of the coronavirus emergency, Japan did not publicize the reality of the coronavirus spread

Nancy Snow

nsnow@fullerton.edu

1 Professor Emeritus, California State University, Fullerton, CA, USA

2 Department of Global Studies, Kyoto University of Foreign Studies, 6 Saiinkasamechō, Ukyo Ward, Kyoto 615-8558, Japan through widespread documentation of infection numbers. Testing was minimized except for those with severe symptoms in need of immediate hospitalization. The government's nationwide messaging focused on emphasizing people's normative behavior: Japan's culturally-based hygienic standards would curtail widespread infection. ${ }^{4}$ This mask diplomacy explanation held up as a primary contributing factor in global media's assessment of Japan's containment success. $^{5}$

In May 2020, Prime Minister Shinzo Abe proclaimed: "We were able to contain the virus in a month and a half in a uniquely Japanese way. We showed the power of the Japanese model.” He added that hosting a "complete Tokyo Games" in 2021 would serve as "the symbol for victory of mankind against the novel coronavirus next summer." This was a major turnaround in tone and impression from when the Yokohama-moored Diamond Princess cruise ship had come to be dubbed the world's largest floating petri dish. The ship was once the meme to define Japan's crisis communications' mishandling of the coronavirus. ${ }^{6}$

\footnotetext{
1 Japan Special: Go 2020! Monocle Issue 129, December 2019/January 2020.

2 Joanna Airth, What the Japanese can teach about super-ageing gracefully, BBC News, March 30, 2020.

${ }^{3}$ Nancy Snow, Under The Security Umbrella: Japan's Weak Storytelling to the World, Defence Strategic Communications Vol. 8, July 2020. 10.30966/2018.RIGA.8.5.

4 Julian Ryall, How Japan's mask culture may have saved lives from across the continent, Deutsche Welle, October 19, 2020.

5 Alyssa Pereira, What mask use looks like in 10 countries compared to the U.S, San Francisco Chronicle, July 5, 2020.

6 Nancy Snow, Japan's government has failed coronavirus communications test, Nikkei Asia, February 21, 2020.
} 
From Abe to his successor Yoshihide Suga, the myopia over hosting the Olympic Games derailed Japan's effective handling of the coronavirus, along with a host of other communication problems, including sexism at the top levels of management. ${ }^{7}$

Closely related to the Olympics mismanagement, the government of Japan was shortsighted in not allowing the science, health and welfare community to direct public policy. It was also irresponsible in not communicating consistent policies that were easy to follow. The behavioral-driven "Three C's" approach placed the responsibility for infection squarely on the Japanese people, but it needed to be balanced with the government's effort to accurately communicate rates of infection as well as their cluster sites.

Japan had been dedicated for years to improving its image and reputation in the world through monitoring international public opinion and correcting what it viewed as an overly critical foreign press agenda. What it missed were the fundamentals of leadership management in crisis: genuine empathy and compassion in times of uncertainty and insecurity.

A Kyodo News survey released in May 2020 reported that $84 \%$ of the Japanese people felt insecure in their personal lives. This did not begin with the pandemic but extended these feelings of discontent. More people were seeking financial assistance for households at the same time that the government was asking them to do more with less. The public was justified that the government seemed overly concerned with its own political legacy at the same time the public was bearing the brunt of Japan's economic downturn.

While Abe was not known as an empathic leader like Prime Minister Jacinda Ardern of New Zealand, he or a designated point person could have engaged in a role of helpful compatriot to overcoming personal misery, not as someone who was dedicated to maintaining his party's dominance or saving the economy. In February 2021, Abe's successor Suga announced the appointment of a new Minister of Loneliness to combat COVID-related suicides, but without a plan or strategy that could explain to the public what a difference this would make.

Mr. Abe once wrote about a beautiful Japan and to that end unveiled a newer Abenomics initiative he called Ichi oku so katsuyaku ("100 million people making efforts as one"). He spoke often about women's empowerment and making women shine at home and at work, but global gender equality rankings for Japan remain at historic lows, 120th out of 156 countries in 2021. In the pandemic economy, women and their children disproportionally bear the brunt of its associated pains. Japan's Welfare Ministry data shows

\footnotetext{
7 BBC News, Yoshiro Mori: Tokyo Olympics chief steps down over sexism row, February 12, 2021.
}

that women still represent $90 \%$ of single parent households while earning only half the annual income of single fathers.

What the Japanese public expected was an understanding government that showed sensitivity to the economic misery that partnered with the pandemic. As misery increased, including a rise in suicides, especially among women, the government's approval ratings dropped. To its credit, the government leadership in Japan ultimately conceded a certain resignation that it was no longer possible to host a perfect Olympic Games. ${ }^{8}$

As we know now, a narrative focused on putting people and public health first never happened. Would it have even mattered to Japan's soft power reputation? It is too soon to tell. Japan's soft power reputation precedes it, nourished by its nice Japan public face. ${ }^{9}$ It has maintained strong rankings as a non-interventionist nation-state with a finely crafted peaceful image in the world.

The Games went ahead in an oppressively hot and humid atmosphere that led to complaints among athletes. Fresh off his latest Grand Slam win at Wimbledon, Novak Djokovic said after losing at the Olympics, "I've played tennis now professionally for 20 years, and I've never faced this kind of conditions in my entire life on a consecutive daily basis." 10 During the first week of competition, over 8000 citizens landed in the hospital for possible heat stroke, about twice the usual number. Tokyo's summer earned its own dubious award, a CNN headline for "the worst in the history of the Olympics." 11

From the start, the truth about Tokyo summers could have been told but that wouldn't have fit the requirement to hold the Games when it suited media broadcasters and IOC's profit from the sale of these broadcasting rights. In the Japanese government's official proposal to host the Olympics in July/ August 2020, the words used suggested a meteorological paradise: "With many days of mild and sunny weather, this period provides an ideal climate for athletes to perform their best."

The domestic blunders and outright lies that packaged Tokyo 2020 will have some negative spillover effect among

\footnotetext{
${ }^{8}$ See Yuri Kageyama and Stephen Wade, Some medical experts unconvinced about holding Tokyo Games, Associated Press, March 30, 2021; Nancy Snow, The cringeworthy countdown to the Tokyo Olympics, Nikkei Asia, April 28, 2021; CBS News, Olympic organizers update COVID rules to mitigate risk despite relatively low vaccination rates, April 28, 2021.

${ }^{9}$ Nancy Snow, A Test for Cool (and Nice) Japan: Press Relations, Huffington Post, May 4, 2015.

10 Tom Morgan and Pippa Field, 'If I die, who will take responsibility': Tennis players wilt in Tokyo heat with Paula Badosa leaving court in wheelchair, The Telegraph, July 28, 2021.

11 Amanda Sealy and Selina Wang, Heat and humidity make 'Tokyo Summer the worst in the history of Olympics,' CNN, July 30, 2021.

12 Dan Wetzel, Japan's Olympic organizers lied about its weather, and now athletes are paying the price, Yahoo News, July 25, 2021.
} 
foreign populations, but especially if viewed from a top down lens. Government may have failed in its management, but the people involved did not. Going forward, much will depend on the country's ability to re-tell its story to the world beyond a pandemic Olympics to that of trusted sustainability partner and place that, post-pandemic, everyone will want a chance to get to know or visit. Originally the Tokyo Olympics were to show the world that Japan was back from the triple disaster known as 3/11. Redemption, resilience and renewal were values associated with that theme. A new Kishida administration, combined with a public that has found its collective voice to speak up and carve out its own path, can show the world that these values still apply, especially in strengthening Japan's public diplomacy.

Publisher's Note Springer Nature remains neutral with regard to jurisdictional claims in published maps and institutional affiliations.
Nancy Snow is Pax Mundi ("Distinguished") Professor of Public Diplomacy, Kyoto University of Foreign Studies. In 2020 she held the Walt Disney Faculty Chair in Global Media and Communications, Schwarzman College, Tsinghua University. She is Professor Emeritus of Communications at California State University, Fullerton. Snow earned a Ph.D. from the School of International Service, American University, Washington, D.C. and a B.A. in political science from Clemson University. She completed a Presidential Management Fellowship at the U.S. State Department and U.S. Information Agency. Her visiting faculty appointments include Israel, China, and Japan, as well as at two flagship master's programs in public diplomacy, University of Southern California Annenberg School and Syracuse University Newhouse School. A two-time Fulbright scholar (Germany, Japan) and Abe Fellow (Keio University), Snow is author, editor, or co-editor of 14 books, including The SAGE Handbook of Propaganda and the second edition Routledge Handbook of Public Diplomacy (with Nicholas J. Cull). She is opinion writer for Nikkei Asia and has published over three hundred print, online, and scholarly journal articles and reviews. 